\title{
Biyoaktif Besin Peptitleri ve Sağlık Üzerine Etkileri
}

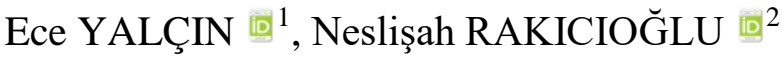

\begin{abstract}
ÖZ
Biyoaktif besin peptitleri, vücutta birçok biyolojik işlevin kontrolünde yapısal özelliğe sahiptir. Bu bileşenlerin olumlu etkilerini gösterebilmeleri için fizyolojik olarak gerçekçi düzeyde ve ölçülebilir etki göstermesi gerekmektedir. Biyoaktif peptitler; fizyolojik tepkimelerin indüklenmesine yol açan, hedef hücreler üzerindeki spesifik reseptörlere bağlanma yoluyla fizyolojik fonksiyonu olan, hormon veya ilaç benzeri aktiviteye sahip peptitler olarak tanımlanmıştır. Biyoaktif peptitler genellikle 3-20 amino asit kalıntısı içermekte ve temel protein yapısındayken etkinlik göstermemektedir. Bitki ve hayvan proteinlerinin temel yapısında bulunan biyoaktif besin peptitlerinin etkinlik gösterebilmesi için peptit sekanslarının serbest hale gelmesi gerekmektedir. Bu peptitler çoğunlukla enzimatik hidroliz, gastrointestinal sistemde sindirim enzimleri ile hidroliz ve fermentasyon yoluyla üretilmektedir. Yapılan in vitro ve in vivo çalışmalarda; biyoaktif besin peptitlerinin antihipertansif, hipolipidemik, antioksidan, antiinflamatuar aktiviteye sahip olduğu bildirilmiştir. Bu nedenle, son yıllarda kronik hastalıkların önlenmesinde, tedavisinde ve genel sağlığın korunmasında biyoaktif besin peptitlerin kullanımına yönelik çalışmalar artmaktadır. Bu derleme yazının amacı, biyoaktif besin peptitlerini ve sağllk üzerine olan etkilerinin değerlendirilmesidir.
\end{abstract}

Anahtar Kelimeler: Proteinler; peptitler; fermentasyon; sağlık.

\section{Bioactive Food Peptides and Effects on Health}

\begin{abstract}
Bioactive food peptides have many structural features in the control of various biological functions in the body. These components need to be measurable at a physiologically realistic level. Bioactive peptides have been identified as peptides with hormone or drug-like activity that have a physiological function by binding to specific receptors on target cells leading to the induction of physiological responses. Bioactive peptides usually contain between 3 and 20 amino acid residues and remain inactive while the sequences are in the basic protein structure. Inactive bioactive food peptides in the primary structure of plant and animal proteins are activated by releasing the peptide sequences. These peptides are mainly produced by enzymatic hydrolysis, hydrolysis with digestive enzymes in the gastrointestinal tract and fermentation. In vitro and in vivo studies showed that bioactive food peptides have antihypertensive, hypolipidemic, antioxidant and anti-inflammatory activity. Therefore, studies on the use of bioactive food peptides have been increasing in the treatment of chronic diseases and general health. The purpose of this review article is to investigate the effects of bioactive food peptides on health.
\end{abstract}

Keywords: Proteins; peptides; fermentation; health.

\section{GíRIŞ}

Proteinler; besin işleme yöntemlerinden sıklıkla etkilenen, vücut için önemli olan birçok fonksiyon ve biyolojik özelliğe sahiptir (1). İşleme yöntemleri sürecinde asitleştirme gibi pH değişimleri, asilasyon, glikosilasyon, fosforilasyon gibi kimyasal işlemler, ısıl işlemler ve fermentasyona bağlı olarak proteinlerin yapısı değişmektedir. Bu değişiklikler, dokusal/organoleptik özelliklerde gelişme, ürünün daha iyi stabilitesi, biyoaktif peptitlerin oluşumu gibi olumlu etkiler sağlarken, bir veya daha fazla amino asidin modifikasyonu, alerjenik bileşiklerin açığa çıkması gibi nedenlerden dolayı

1 Hacettepe Üniversitesi, Sağlık Bilimleri Fakültesi, Beslenme ve Diyetetik Bölümü, Ankara, Türkiye 
vücudu olumsuz yönde etkileyebilmektedir (2). Biyoaktif maddeler, "biyolojik süreçler veya substratlara etki ederek vücut fonksiyonu üzerinde etkili olan” besin bileşenleri olarak tanımlanmaktadır (1). Biyoaktif besin peptitleri çoğunlukla süt, yumurta, et gibi hayvansal kaynaklı proteinlerde ve soya, kurubaklagiller, buğday, kanola gibi bitkisel kaynaklı proteinlerde de bulunmaktadır (3). Biyoaktif peptitlerin antimikrobiyal, antioksidan, antiinflamatuvar özelliklerine bağlı olarak hipertansiyon, kolesterol düzeyi, obezite, diyabet, kanser, nörolojik hastalıklar üzerine olumlu etkileri vardır. Genellikle enzimatik hidroliz, gastrointestinal sistemde (GİS) sindirim enzimleri ile hidroliz ve başlangıç kültürlerini kullanarak fermentasyon yoluyla biyolojik aktiviteye sahip peptitler üretilmektedir (4). Bu derleme yazının amacı, biyoaktif besin peptitleri ve sağlık üzerine olan etkilerinin değerlendirilmesidir.

\section{Biyoaktif Besin Peptitleri ve Kaynakları}

Biyoaktif peptitler beslenme ve ilaç terimlerini içeren nutrasötikler olarak da kabul edilmektedir (5). Proteazlar tarafindan proteinlerin kısmi sindirimleri sonucunda, spesifik biyolojik özelliklere sahip peptit sekansları üretilmektedir (6). Biyoaktif peptitler, hücrede büyük ön peptitler şeklinde sentezlenen proteinler olup, daha sonra parçalanarak aktif ürünler vermek üzere modifiye edilmektedir (4). En çok süt ve süt ürünlerinden izole edilen biyoaktif potansiyele sahip peptitler yumurta, et, balık gibi hayvansal kaynaklı proteinlerde ve buğday, mısır, pirinç, mantar, kabak gibi farklı bitkisel protein kaynaklarında bulunmaktadır $(7,8)$. Başta 'BİOPEP' veri tabanı olmak üzere günümüzde 3000'den fazla biyoaktif peptit tanımlanmıştır (9). Biyoaktif besin peptitlerinin antimikrobiyal, antitrombotik, antioksidan, kan basınc1 ve kolesterol düşürücü, minerallerin biyoyararlılığını artıcı olmak üzere çok çeşitli fonksiyonları bulunmaktadır $(1,4)$. Ayrica, peptitler sinyal yolaklarından sorumlu olan genlerin ekspresyonunu düzenlemektedir (10). Biyoaktif besin peptitleri genellikle, beklenen besin değerlerinin üzerinde biyolojik aktiviteleri olan kısa peptitlerdir (3-20 amino asit). $\mathrm{Bu}$ peptitler çoğunlukla doğal proteinler içinde işlevsel olarak etkisizdir ve 'biyoaktif' rollerine ulaşmak için proteoliz (in vivo sindirim, in vitro enzimatik hidroliz) veya bakteriyel fermentasyon ile izole olması gerekmektedir (11). Bu bileşenler, biyoaktif olarak kabul edilebilmeleri için fizyolojik olarak gerçekçi düzeyde, ölçülebilir bir biyolojik etki göstermelidir. Ölçülen 'biyoaktivitenin' ise; toksitite, alerjinite ve mutajenite gibi sağlığı olumlu yönde etkileme potansiyeline sahip olması gerekmektedir (7).

Besinlerdeki proteinlerden, enzimatik hidrolizle (bitki veya mikroorganizma kaynaklı proteolitik enzimler kullanılarak), sindirim enzimleri ile hidrolizle (uyarılmış gastrointestinal sindirim) veya başlangıç kültürlerini kullanarak fermentasyon yoluyla biyoaktif peptitler meydana gelmektedir. Doğada biyoaktif peptitlerinin miktarı düşük olduğundan kimyasal olarak, rekombinat DNA teknolojisi ve transgenetik bitki ve hayvanlarda üretilmektedir $(12,13)$. Bilinen biyoaktif peptitlerin çoğu, in vitro enzimatik hidroliz veya fermentasyon yoluyla üretilmektedir (3). Örneğin sütte bulunan biyoaktif peptitler; süt proteini hidrolizatları ve fermente edilmiş süt, peynir gibi çoğu süt ürününde tanımlanmıştır (14).
Peptitlerin özellikleri boyut, net yük ve hidrofilik yapıya bağlı olarak değişmektedir (3). Peptitler tatlı, umami, acı başta olmak üzere birçok tada sahiptir (10). Tatlı tada sahip peptitler, yüksek moleküler ağırlıklı polipeptitlerdir. Tadiyla en iyi bilinen peptit, L-aspartil L-fenilalanin metil ester, yani enerji vermeyen tatlandırıcı olarak kullanılan aspartamdır. Umami tat ise temel olarak glutamat tarafından sağlanmaktadır. Birçok peptitin umami tadının olduğu bildirilmiştir. Sekansı H-Lys-GlyAsp-Glu-Glu-Ser-Leu-Ala-OH olan olan oktapeptit 'lezzetli peptit' olarak adlandırılmıştır. Dipeptitlerden (HAsp-Glu-OH gibi) H-Glu-Pro-Ala-Asp-OH'ye kadar izole edilmiş peptitler ekşi tada sahiptir. Hidrofobik yan zincirlere sahip aminoasit kalıntılarını içeren birçok peptitin ise acı tadı vardır $(10,15)$. Genellikle enzimatik hidrolizle acı tat oluştuğu için bekletilmiş veya fermente edilmiş besinlerde acı tat diğer tatlara göre daha fazla bulunmaktadır. Arjinin ve prolinin birlikte bulunduğu peptitler de acı tada sahiptir (15).

\section{Biyoaktif Besin Peptidlerinin Oluşumu}

\section{Enzimatik Hidroliz}

Fonksiyonel peptitlerin üretilmesi için en yaygın, güvenilir ve hızlı yöntem enzimatik hidroliz yoluyla proteinlerin yıkımıdır $(13,14,16)$. Enzimatik hidroliz yönteminde, proteine belirli bir $\mathrm{pH}$ ve sicaklıkta enzimatik işlem uygulanmaktadır (12). Proteazlar, spesifikliği yüksek proteinlerdeki peptit bağlarının hidrolizini katalize etmektedir. Farklı protein kaynakları, enzimler ve hidroliz koşulları, farklı biyolojik aktiviteleri olan peptitleri ortaya çıkartabilir (13). Bilinen biyoaktif peptitlerin çoğu, pepsin, tripsin ve kimotripsin gibi gastrointestinal enzimlerin etkisiyle salınmaktadır (16). $\mathrm{Bu}$ yöntem, kolay ve genellikle mikrobiyal fermentasyondan daha kısa bir reaksiyon süresine sahip olması nedeniyle diğer yöntemlere göre daha avantajlıdır (12). Kimotripsin, alkalaz, termolisin, pankreatin gibi farklı orijinli çoklu enzimler de biyoaktif peptitleri üretmek için kullanılmaktadır (14).

\section{Mikrobiyal Fermentasyon}

Besinlerdeki proteinlerden proteolitik başlangıç kültürleri ile fermentasyon, bir başka biyoaktif peptit üretim yöntemidir (17). Süt endüstrisinde endüstriyel ölçekte kullanılan birçok başlangıç kültürü doğada proteolitiktir. Lactococcus lactis, Lactobacillus delbrueckii ssp bulgaricus ve Lactobacillus helveticus gibi kültürler kullanılarak, çeşitli biyoaktif peptitleri içeren fermente süt ürünleri üretilmektedir. Bu kültürler hücre duvarına bağlı proteazlar ve dipeptidazlar, tripeptidazlar, aminopeptidazlar ve endopeptidazlar gibi peptidazları içermektedir. $\mathrm{Bu}$ başlangıç kültürleri, anjiyotensin dönüştürücü enzim (ACE) inhibitör peptitler, antimikrobiyal, antioksidan ve immünomodülatör peptitler gibi çeşitli peptitlerin üretilmesine yardımcı olmaktadır (14). Bununla birlikte, fermente ürünler sıklıkla, canlı ve ölü bakteri hücreleri, ekzopolisakaritler, bakteriyosinler gibi bazı biyolojik işlevleri olan diğer bileşikleri içerdiğinden; oluşan biyoaktivitelerin fermentasyon sırasında oluşan peptitlerden kaynaklanma durumu tam bilinmemektedir (18).

3. Sindirim/Mikrobiyal Enzimleri ile Gastrointestinal Sindirim

Biyoaktif peptitler kısa uzunluklu normal protein molekülleri olup mide ve pankreas proteazları, firçamsı 
yüzey proteazları ve sitozolik plazma proteazları tarafından sindirime ve bozulmaya karşı duyarlıdır (5). Böylece biyoaktif peptitler, gastrointestinal sistemde (GİS) proteinlerin sindirimi sırasında üretilmektedir (16). Besinlerdeki proteinler mideye girdikten sonra denatüre olur ve hidroklorik asit pepsinin etkisiyle kısmen parçalanarak biyoaktif peptitler açığa çıkmaktadır. Örneğin, sütte bulunan peptitler çoğunlukla pepsin, tripsin veya kimotripsin gibi proteaz enzimlerin etkisine bağlı olarak kazein yıkımı sırasında salınmaktadır (14).

\section{Biyoaktif Besin Peptitlerinin Vücutta Kullanımı}

Biyoaktif besin peptitleri bitki ve hayvan proteinlerinin temel yapısında aktif olmayan amino asit dizileri olarak şifrelendikten sonra tüketimle in vitro veya sindirim yolunda fermentasyon, hidroliz yoluyla serbest bırakılmaktadır (3). Proteinler ve peptitler; peptin, tripsin, kimotripsin gibi gastrointestinal sistemde bulunan farklı enzimler ve epitel hücrelerinin yüzeyinde bulunan peptidazlar tarafından çeşitli uzunluklardaki peptitlere hidrolize edilirler (19). Biyoaktif peptitler gastrointestinal lümenden emildikten sonra dolaşıma geçerek hedeflenen organ veya sisteme ulaşmaktadır (5). Serbest bırakılan biyoaktif besin peptitleri, ince ve kalın bağırsakta biyoaktivite göstermektedir (8). Genellikle protein hidrolizatları ve peptitleri, temel proteinlere kıyasla daha yüksek biyoaktivite göstermektedir. Hidroliz için kullanılan enzimler, işleme koşulları ve elde edilen peptitlerin boyutu gibi birçok faktör, peptitlerin enterositler boyunca emilimini ve hedef dokulardaki biyoyararlanımını büyük ölçüde etkilemektedir (3). Örneğin, zincir uzunluğu arttıç̧a biyoaktif peptitlerin etkinliği azalmaktadır. Normal sindirim ve emilim sürecinden kaçan peptitler, hücre arası boşluktan geçişi sağlayan parasellüler ve enterositlerin firçamsı kenarları boyunca geçişi sağlayan transsellüler yol olmak üzere iki mekanizma ile bağırsak mukozasına geçmektedir. Dipeptitler ve tripeptitler, bu iki bağımsız sistem tarafından taşındıkları için serbest amino asitlere kıyasla ince bağırsaktan daha hızlı emilmektedir (16). Emilen peptitler ve amino asitler genel dolaşımda serbest bırakılmadan önce metabolize olmaları için karaciğere taşınmaktadır (5).

Besin işleme yöntemleri biyoaktif peptitlerin biyolojik aktivitesini önemli ölçüde etkilemektedir. Ultrason, 1sı ve 1şınlama gibi fiziksel işleme yöntemleri proteinin yapısını ve fonksiyonlarını değiştirir. Bu işlemler aynı zamanda maillard reaksiyonlarına ve alerjen bileşenlerin üretimine yol açmaktadır $(20,21)$. Besin işleme yöntemleri bazı peptitlerin aktivitesini azaltırken, bazı peptitlerin aktivitesini arttırmaktadır. Örneğin, 1sıtma işlemleri bazı peptitlerin aktivitelerini azaltırken, laktoalbumin ve lizozimin aktivitilerini arttırmaktadır. $\mathrm{Bu}$ nedenle, biyoaktif peptitlerin biyoaktifliklerini korumak için işlenebileceği en uygun koşulları belirlemek önemlidir (21).

\section{Biyoaktif Besin Peptitlerinin Sağlık Üzerine Etkileri}

Farklı enzimler ile aynı kaynak proteinden farklı fizyolojik ihtiyaçlara uygun biyolojik fonksiyonlara sahip biyoaktif peptitler üretilmektedir (12). Genellikle, bu peptitlerin hastalıklara karşı olan etkisi sentetik peptidomimetik ve ilaçlardan daha düşüktür. Ancak biyoaktif besin peptitlerinin güvenilir, maliyetinin düşük ve esansiyel amino asitlerin kaynağı olması nedeniyle birçok yarar ve avantajı bulunmaktadır (3).

\section{Antioksidan Etkileri}

Bir peptitin antioksidan özellik göstermesi için, metal iyonlarını şelatlaması veya tek elektron aktarma kapasitesine sahip çok sayıda amino asit içermesi gerekmektedir. Hidrofobik amino asitlerin çoğunun, peptitlerin radikalleri süpürme özelliğinden dolayı yüksek antioksidan kapasiteye sahip olduğu bildirilmiştir. Glisin, prolin, lösin, hidrofobik aminoasit kalıntıları, antioksidan peptitlerin \%33,7'sini oluşturmaktadır (22). Bu amino asitlerin, su-lipit ara yüzündeki peptitlerin seviyesini arttırarak serbest radikallere ulaşımı kolaylaştırdığı bildirilmiştir. Ayrıca tirozin, fenilalanin, prolin, alanin ve histidin gibi aromatik aminoasitler sahip oldukları protonu vererek serbest radikalleri süpüren yüksek antioksidan aktivite göstermektedir $(2,22)$. Asidik amino asitlerin ise karbonil ve amino gruplariyla yan zincirde metal iyonlarını şelatlayarak antioksidan etkileri bulunmaktadır (2). Farklı enzimlerle hidrolizden sonra bezelye, soya, balık, kinoa, keten tohumu, süt, peynir altı suyu ve yumurtada birçok antioksidan peptit tanımlanmıştır $(11,22)$. Örneğin, süt proteinlerinden elde edilen peptitlerin, esansiyel yağ asitlerinin enzimatik (lipoksijenaz) ve enzimatik olmayan peroksidasyonunu önleyen antioksidan özellikleri bulunmaktadır $(8,11)$.

\section{Antihipertansif Etkileri}

Kan basinc1, fizyolojik olarak renin-anjiyotensin sistemi (RAS) ve kinin-nitrik oksit (NO) sistemi tarafindan kontrol edilmektedir. Anjiyotensin dönüştürücü enzim, bu regülasyonda yer alan temel mekanizmalardan biridir (3). Anjiyotensinojen inaktiftir ve renin ile anjiyotensin 1 'e dönüşmektedir $(3,14)$. Bu reaksiyon, RAS yolağının ilk ve hız sınırlayıcı adımıdır. Daha sonra anjiyotensin I'den ACE aktivitesi ile C terminalden histidil kalıntısı (His-Leu dipeptidi) çıkarak, anjiyotensin II üretilir. Biyoaktif besin peptitleri, ACE'yi inhibe eder ve anjiyotensin I'den vazokonstriksiyona neden olan hormon anjiyotensin II'ye dönüşümü engellemektedir. Ayrıca, kinin-NO sistemi, güçlü bir vazodilatör olan nitrik oksit sentazın (NOS) aktivasyonuna neden olan hücre içi $\mathrm{Ca}^{2+}$ konsantrasyonunu artıran reaksiyonları ortaya çıkararak, antihipertansif etkisi olan bradikinin üretimine neden olmaktadır. Anjiyotensin dönüştürücü enzim, bradikinin seviyesini düşürür. Böylece artan ACE konsantrasyonu, vazodilasyonun önlenmesi ve vazokonstriksiyonun aktivasyonuna neden olmaktadır. Bazı biyoaktif besin peptitleri, ACE'nin inhibitörleri olarak antihipertansif ajan yerine kullanılmaktadır (3). Anjiyotensini inhibe edici peptitler olarak nitelendirilebilecek birçok protein veya protein k1smı vardır $(1,14)$. Peptitlerin ACE'ye bağlanmas1, peptitlerin C-terminalinden kuvvetli bir şekilde etkilenmektedir. Hidrofobik amino asitler, temel ACE inhibitörüdür. Ayrıca, arjinin ve/veya lösin kalıntılarından gelen pozitif yük, ACE inhibitör aktiviteyi artırmaktadır (1). Farelerde yapılan bir çalışmada süt kazeininden elde edilen valil prolil prolin (VPP) ve izolösil prolil prolin (IPP) tripeptitleri, izole edilmiş aortta vazorelaksasyon (damar basıncını azaltıcı) etki göstermiş ve insan umbilikal damar endotel hücre kültürlerinde ise NO üretimini artırdığı bildirilmiştir (23). Sindirim enzimi olan pepsin ve tripsin, ACE inhibitör aktiviteleri gibi çeşitli biyoaktif özelliklere sahip birçok 
peptidi üretmek için kullanılmaktadır. Ayrıca antihipertansif peptitler, bovin aS2-kazein ve kaprin ve ovinden gelen makropeptidlerin triptik hidrolizi ile de üretilmektedir (14). Hipertansif farelerde yapılan başka bir çalışmada tripeptit içeren fermente süt ürünlerinin 14 haftalık kullanımının kan basıncını azalttığı bildirilmiştir (24). Kefirdeki biyoaktif peptitleri değerlendiren bir çalışmada; 34 tane ACH inhibitör aktivitesine sahip peptit tanımlanmıştır (25). Yapılan çalışmalar sonucunda balık, yumurta ve soya proteinlerinin, ACE inhibe edici peptitler olduğu bildirilmiştir $(14,26,27)$. Doğal kaynaklardan antihipertansif peptitler fermentasyon veya protein hidrolizi ile elde edilmektedir (18).

\section{Antitrombotik Etkileri}

Normalden daha fazla kan pıhtılaşmasının olması glikoz ve lipoprotein metabolizması regülasyonunun bozulmasına, obezite, metabolik hastalıklar ve mortalitenin artmasına neden olmaktadır (1). Antitrombotik peptitler, trombozu önleyen protein fraksiyonlarına sahiptir. $\mathrm{T}$ yüzeyindeki belirli özel bölgeye fibrinojen bağlanmasını ve trombositlerin birikmesini inhibe etmektedir (13). Krismosin ve $\alpha$ kazein gibi süt pıhtılaşma proteinleri, trombin ve fibrinojen içeren kan pıhtılaşma mekanizmasına benzer mekanizmaları içermektedir (14). Antitrombotik peptit olan k-kazein, yenidoğan plazmasında sütün sindiriminden sonra tanımlanmıştır. İnsanda spesifik bir biyoaktivitesi bildirilmemiştir (1).

\section{Hipolipidemik ve Hipokolesterolemik Etkileri}

Proteinlerin proteaz ile hidrolizi sonucunda kolesterol ve lipid düşürücü aktivitelere sahip olan peptit sekansları serbest hale gelmektedir. Hipolipidemik ve hipokolesterolemik peptitler soya, süt, karabuğday, yumurta beyazı ve balık proteininde bulunmaktadır. Ancak enzimatik hidroliz besinlerdeki proteinlerin lipid düşürücü aktivitesinin azalmasına neden olabilmektedir (3). Lipit düşürücü peptitler üzerinde yapılan çalışmalar, genellikle soya proteini hidrolizatları ve peptitleri üzerinde yoğunlaşmıştır $(3,28)$. Soya proteininde genellikle bu etki soya 7S globulin ile olmaktadır (3). Yapılan bir çalışmada soya fasulyesi proteininden elde edilen peptitlerin hepatositlerde düşük yoğunluklu lipoprotein (LDL) reseptörlerinin transkripsiyonunu etkilediği bildirilmiştir (29). Ayrıca 7S-peptitlerin, triasilgliserol sentezi ile ilgili gen ekspresyonlarını değiştirerek, trigliserit seviyesini azaltıcı etki gösterdiği ve LDL reseptörlerinde mRNA ekspresyonundaki artıştan dolayı hepatositlerde Apo B-100 birikimini azalttı̆̆ bulunmuştur (3). Borodini ve ark. (28) yaptığı çalışmada, hiperkolesterolemisi olan 29 bireyden oluşan 2 gruba, 2 ay boyunca bir gruba günde 30 gram soya fasulyesi protein izolatı içeren çerez, diğer gruba ise yağsız lor proteini verilmiştir. Çalışma sonunda soya fasulyesi protein izolatı tüketen bireylerde serum kolesterol düzeyi anlamlı olarak azalırken, yüksek dansiteli lipoprotein konsantrasyonu artmıştır. Gen ekspresyonundaki değişikliklere ek olarak, soya proteini hidrolizatları ve peptit bileşenler bağırsaktaki safra asitleri ve sterollerin fekal atımının artmasına neden olarak hipokolesterolemik aktivite gösterdiği bildirilmiştir (3).

Lunasin, 43 tane amino asit içeren bir polipeptit olup soya fasulyesi, arpa, çavdar ve buğdayda bulunur ve hipokolesterolemik aktivite göstermektedir. Ayrıca ticari

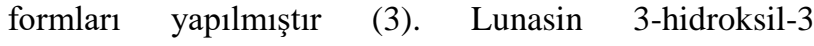
metilglutoril koenzim redüktaz üretimini ve histon asetilasyonunu bloke ederek kolesterol biyosentezini azaltmaktadır. Ayrıca, plazma LDL reseptörlerinin hücresel üretimini arttırarak LDL kolesterolünün uzaklaştırılmasını sağlamaktadır (30).

\section{Obezite Üzerine Etkileri}

Bazı biyoaktif peptitlerin vücuttaki açlık tokluk mekanizmalarıyla ilişkili olarak obezite üzerinde etkili olabileceği bildirilmiştir (31,32). Soya ve kazein kaynaklı peptitler, kolesistokinin-A reseptörleri ve sinir sistemi aktiviteleri ile doygunluğu sağlamaktadır (31). Whey proteinleri ise, gastrik inhibe edici peptit (GIP) salınımını uyarır ve tokluk hormonu olan kolesistokinin salgısını arttırmaktadır (1). Japonya'da yapılan bir çalışmada yaşları 22-60 olan 26 birey iki gruba ayrılarak, bir gruba 8 hafta boyunca günde $300 \mathrm{mg}$ laktoferrin içeren kapsül verilmiştir. Plasebo grubuna kıyasla laktoferrin verilen grupta vücut ağırlığı, beden kütle indeksi (BKI) ve kalça çevresinde anlamlı azalma olduğu bildirilmiştir (32). Kore'de yapılan bir çalışmada yaşları 19-65 olan hafif şişman/obez 34 bireye, 12 hafta boyunca her öğün sonrasında $4.5 \mathrm{~g}$ soya fasulyesi peptitleri takviye olarak verilmiştir. Çalışma sonunda bireylerin BKİ, vücut yağ yüzdesi, trigliserit ve total kolesterol seviyelerinde azalma, HDL kolesterol (HDL-K) seviyesinde artış olduğu bildirilmiştir (33).

\section{Antikanser Etkileri}

Beslenme, kanser etiyolojisinde oldukça önemli bir rol oynamaktadır (14). Süt, soya proteinleri ve protein fraksiyonlarının çeşitli kanserleri tedavi etme potansiyeline sahip olduğu bildirilmiştir (14,21). Biyoaktif peptitler bu etkilerini kanser hücrelerinin profilerasyonu ve apoptozu inhibe ederek göstermektedir (21). Bu etkiler biyoaktif peptitlerin yapısına göre değişmektedir. Örneğin; kazein, whey proteinlerine kıyasla serbest misel yapıya sahip olduğu için mutajene daha kolay ulaşır ve bu nedenle antimutajenik etkisi daha fazladır (14). Bu peptitler glutatyon sentezinin artması ve bunun sonucunda bağışıklık ve antioksidan aktivitenin uyarılmasıyla ilişkili olarak antikanserojenik etki göstermektedir. Ayrıca, antioksidan etkilerinden dolayı kanser tedavisinin yan etkilerine karşı olumlu etkisi bulunmaktadır (34).

\section{Antidiyabetik Etkileri}

Dipeptidil peptidaz 4 inhibitörü (DPP-IV), kan şekeri seviyesini düzenleyen insülinotropik metabolik hormonların aktivitelerini kontrol eden her yerde bulunan bir proteazdır. Süt, kollajen, kanola, tavuk yumurtası, yulaf ve buğday, mısır, kinoa ve kenevir gibi bazı besin proteinlerinin DPP-IV inhibitör peptit dizilerini içermektedir. Bu peptitler genellikle dipeptit yapıdadır (22). Soya fasulyesi gibi birçok fermente besin 3T3-L1 hücrelerinde glikoz alımını, insülin salgısını uyaran ve PPAR- $\gamma$ aktivitesini azaltan düşük moleküler ağırlıklı peptitleri içermektedir (21). Siyah fasulye protein hidrolizatlarının glikoz transporter 2 (GLUT-2) ve sodyum bağımlı glikoz transporter 1 (SGLT-1)'i inhibe ederek glikoz seviyesini düşürdügü bildirilmiştir (35). Ayrıca bazı peptitler $\alpha$ - amilazı inhibe ederek, diyetle alınan nişastaların emilimini azaltmaktadır (5). Ancak bu etkilerin çoğu hücre kültürü ve hayvan çalışmaları sonucunda elde edilmiştir $(21,35)$. 


\section{8. İmmünmodülatör ve İnflamatuvar Etkileri}

Biyoaktif peptitler antioksidan aktivite, immünmodülasyon ve yara iyileşmesini aktive edici göstermektedir. Antimikrobiyal peptitler bakteri, mantar ve virüslerin etkilerini inhibe edici etkiler göstermektedir (21). Anne sütü, inek sütü, yumurta, balık ve et, soya fasulyesi, misir protein hidrolizatlarında immünmodülatör peptitlerler tespit edilmiştir (11). Bu peptitlerin fizyolojik etki mekanizmaları bilinmemektedir, ancak peptitler bağışıklık sistemi hücrelerinin çoğalmasını ve olgunlaşmasını uyarmaktadır. Süt proteinlerinden elde edilen sentetik peptitlerin, insan periferal kan lenfositlerinin proliferasyonunu arttırdı ğ bulunmuştur (4). Yapılan çalışmalarda dipeptit ve tek başına amino asitlerin antiinflamatuvar etki göstermezken, tripeptit yapının inflamasyonu önlediği bildirilmiştir $(36,37)$. Ayrıca immünmodülatör peptitler; insan lenfositlerinin proliferasyonunu, makrofajların fagositik aktivitelerini, antikor sentezini, $\mathrm{T}$ hücrelerinin ve doğal öldürücü hücrelerin çoğalmasını, olgunlaşmasını uyarmaktadır (4).

\section{Biyoaktif Besin Peptitlerinin Güvenirliği}

Biyoaktif peptitler, "Fonksiyonel Besinler" veya "Nutrasötikler” olarak pazarlanan birçok ürünün temel bileşenidir. $\mathrm{Bu}$ ürünlerde biyoaktif peptitler, normal üretim işleminin değiştirilmesiyle zenginleştirilir. Biyoaktif peptitler, ayrıca bazı sağlık arttırıcı etkiler sağlamak için diş macunu, ağız bakım suyu, sakız gibi besin dişı matrislere de eklenmektedir. Ayrıca farmasötik alanda antihipertansif olarak kullanılmaktadır (8).

Biyoaktif peptitlerin güvenli olduğu düşünülmekle birlikte, çok yüksek dozda tüketilmesi durumunda olası yan etki riskleri vardır. Diğer bir olası risk, protein hidrolizatlarında bazı bireylerde alerjik reaksiyonları azaltan ve/veya arttırabilen immünojenik proteinlerin ve peptitlerin varlığıdır (11). Peptitler, reaktif oksijen türleri, okside lipidler ve aldehitler ile tepkimeye girebilir. Ayrica dekarboksilasyon, deaminasyon ve nitrasyon reaksiyonlarına katılabilirler. $\mathrm{Bu}$ durumlar besinlerin matrisindeki peptitlerin kullanılabilirliğini de etkilemektedir (12).

\section{SONUC VE ÖNERILER}

Protein hidrolizatları, belirli besin, tür ve hidrolizin koşullarına bağlı olarak farklı sekans ve uzunluklarda biyoaktiviteye sahip bir peptit havuzundan oluşmaktadır. Biyoaktif besin peptitleri, vücutta biyolojik fonksiyonların kontrolünde birçok yapısal özelliğe sahiptir ve kronik hastalık riskini azaltacak veya önleyecek sekansları bulmaya yönelik yapılan çalışmalar bulunmaktadir. Besin peptitlerinin bu biyolojik etkilerini göstermesinde ve fonksiyonel besinlerin gelişimi için güçlü biyoaktif peptitlerin fonksiyonlarının altında yatan yapılarını anlamak önemlidir. Bu nedenle son dönemlerde biyoaktif besin peptitlerine olan ilgi artmaktadır. Biyoaktif besin bileşenleri bitkisel, hayvansal doğal kaynaklara ek olarak besin takviyesi ve farmasötik biçimde bulunmaktadır. Ancak genel bir öneride bulunmak için güvenilir yöntem ve vücutta kullanılabilirliği ile ilgili kapsamlı klinik araştırmalara ihtiyaç vardır. $\mathrm{Bu}$ nedenle sağlıklı beslenmede, birçok hastalığın önlenmesinde ve tedavisinde, besin çeşitliliğinin sağlanması her zaman önem taşımaktadır.
Yazarların Katkıları: Fikir/Kavram: E.Y., N.R.; Tasarım: E.Y.; Literatür Taraması: E.Y.; Makale Yazımı: E.Y., N.R.; Eleştirel İnceleme: N.R.

Araştırma ve Yayın Etiği Beyanı

Makalede araştırma ve yayın etiğine uyulmuştur.

\section{KAYNAKLAR}

1. Bougle D, Bouhallab S. Dietary bioactive peptides: human studies. Crit Rev Food Sci Nutr. 2017; 57(2): 335-43.

2. Toldrá F, Reig M, Aristoy MC, Mora L. Generation of bioactive peptides during food processing. Food Chem. 2018; 267: 395-404.

3. Udenigwe CC, Aluko RE. Food protein-derived bioactive peptides: production, processing, and potential health benefits. J Food Sci. 2012; 77(1): R11-24.

4. Sharma S, Singh R, Rana S. Bioactive peptides: a review. Int J Bioautomation. 2011; 15(4): 223-50.

5. Chew LY, Toh GT, Ismail A. Application of proteases for the production of bioactive peptides. In: Kuddus M, editor. Enzymes in food biotechnology. India: Elsevier; 2019. p. 247-61.

6. Mazorra-Manzano MA, Ramirez-Suarez JC, Yada RY. Plant proteases for bioactive peptides release: a review. Crit Rev Food Sci Nutr. 2018; 58(13): 214763.

7. Moller NP, Scholz-Ahrens KE, Roos N, Schrezenmeir J. Bioactive peptides and proteins from foods: indication for health effects. Eur J Nutr. 2008; 47(4): 171-82.

8. Hartmann R, Meisel H. Food-derived peptides with biological activity: from research to food applications. Curr Opin Biotechnol. 2007; 18(2): 163-9.

9. Minkiewicz P, Dziuba J, Iwaniak A, Dziuba M, Darewicz M. BIOPEP database and other programs for processing bioactive peptide sequences. Journal of AOAC International. 2008; 91(4): 965-80.

10. Udenigwe CC. Bioinformatics approaches, prospects and challenges of food bioactive peptide research. Trends in Food Science \& Technology. 2014; 36(2): 137-43.

11. Chakrabarti S, Jahandideh F, Wu J. Food-derived bioactive peptides on inflammation and oxidative stress. Biomed Res Int. 2014; 2014: 608979.

12. Chakrabarti S, Guha S, Majumder K. Food-derived bioactive peptides in human health: challenges and opportunities. Nutrients. 2018; 10(11): 1738.

13. Barberis SE, Origone AL, Adaro MO, Bersi G. Bioactive peptides as functional food ingredients. In: Grumezescu AM, Holban AM, editors. Role of materials science in food bioengineering. London, United Kingdom: Elsevier; 2018. p. 147-86.

14. Sultan S, Huma N, Butt MS, Aleem M, Abbas M. Therapeutic potential of dairy bioactive peptides: a contemporary perspective. Crit Rev Food Sci Nutr. 2018; 58(1): 105-15.

15. Temussi PA. The good taste of peptides. J Pept Sci. 2012; 18(2): 73-82.

16. Panchaud A, Affolter M, Kussmann M. Mass spectrometry for nutritional peptidomics: how to analyze food bioactives and their health effects. J Proteomics. 2012; 75(12): 3546-59. 
17. Agyei D, Danquah MK. Rethinking food-derived bioactive peptides for antimicrobial and immunomodulatory activities. Trends in Food Science \& Technology. 2012; 23(2): 62-9.

18. Barberis SE, Origone AL, Adaro MO, Bersi G. Bioactive peptides as functional food ingredients. In: Grumezescu AM, Holban AM, editors. Role of materials science in food bioengineering. Argentina: Elsevier; 2018. p. 147-86.

19. Hernández-Ledesma B, del Mar Contreras M, Recio I. Antihypertensive peptides: Production, bioavailability and incorporation into foods. Adv Colloid Interface Sci. 2011; 165(1): 23-35.

20. Arihara K, Zhou L, Ohata M. Bioactive properties of maillard reaction products generated from food protein-derived peptides. Adv Food Nutr Res. 2017; 81: 161-85.

21. Daliri E, Oh D, Lee B. Bioactive peptides. Foods. 2017; 6(5): 32.

22. Yao S, Agyei D, Udenigwe CC. Structural basis of bioactivity of food peptides in promoting metabolic health. Adv Food Nutr Res. 2018; 84: 145-81.

23. Hirota T, Nonaka A, Matsushita A, Uchida N, Ohki $\mathrm{K}$, Asakura M, et al. Milk casein-derived tripeptides, VPP and IPP induced NO production in cultured endothelial cells and endothelium-dependent relaxation of isolated aortic rings. Heart Vessels. 2011; 26(5): 549-56.

24. Sipola M, Finckenberg P, Korpela R, Vapaatalo H, Nurminen M-L. Effect of long-term intake of milk products on blood pressure in hypertensive rats. J Dairy Res. 2002; 69(1): 103-11.

25. Amorim FG, Coitinho LB, Dias AT, Friques AGF, Monteiro BL, Rezende LCD, et al. Identification of new bioactive peptides from kefir milk through proteopeptidomics: bioprospection of antihypertensive molecules. Food Chem. 2019; 282: 109-19.

26. Castellano P, Aristoy M-C, Sentandreu MÁ, Vignolo G, Toldrá F. Peptides with angiotensin I converting enzyme (ACE) inhibitory activity generated from porcine skeletal muscle proteins by the action of meat-borne Lactobacillus. J Proteomics. 2013; 89: 183-90.

27. Nishibori N, Kishibuchi R, Morita K. Soy pulp extract inhibits angiotensin I-converting enzyme (ACE) activity in vitro: evidence for its potential hypertension-improving action. J Diet Suppl. 2017; 14(3): 241-51.

28. Borodin EA, Menshikova IG, Dorovskikh VA, Feoktistova NA, Shtarberg MA, Yamamoto T, et al. Effects of two-month consumption of $30 \mathrm{~g}$ a day of soy protein isolate or skimmed curd protein on blood lipid concentration in Russian adults with hyperlipidemia. J Nutr Sci Vitaminol. 2009; 55(6): 492-7.

29. Cho SJ, Juillerat MA, Lee CH. Identification of LDLreceptor transcription stimulating peptides from soybean hydrolysate in human hepatocytes. J Agric Food Chem. 2008; 56(12): 4372-6.

30. Lunasin.com [Internet]. Lunasin and heart health, 2017 [Cited: 28.03.2019]. Available from: http://lunasin.com/.
31. Erdmann K, Cheung BW, Schroder H. The possible roles of food-derived bioactive peptides in reducing the risk of cardiovascular disease. J Nutr Biochem. 2008; 19(10): 643-54.

32. Ono T, Murakoshi M, Suzuki N, Iida N, Ohdera M, Iigo $\mathrm{M}$, et al. Potent anti-obesity effect of entericcoated lactoferrin: decrease in visceral fat accumulation in Japanese men and women with abdominal obesity after 8-week administration of enteric-coated lactoferrin tablets. Br J Nutr. 2010; 104(11): 1688-95.

33. Kim MJ, Yang HJ, Kim JH, Ahn CW, Lee JH, Kim $\mathrm{KS}$, et al. Obesity-related metabolomic analysis of human subjects in black soybean peptide intervention study by ultraperformance liquid chromatography and quadrupole-time-of-flight mass spectrometry. J Obes. 2013; 2013: 874981.

34. Martínez Leo EE, Martín Ortega AM, Segura Campos MR. Bioactive peptides-impact in cancer therapy. In: Grumezescu AM, Holban AM, editors. Therapeutic, probiotic, and unconventional foods. London, United Kingdom: Elsevier; 2018. p. 157-66.

35. Mojica L, Gonzalez de Mejia E, Granados-Silvestre MÁ, Menjivar M. Evaluation of the hypoglycemic potential of a black bean hydrolyzed protein isolate and its pure peptides using in silico, in vitro and in vivo approaches. J Funct Foods. 2017; 31: 274-86.

36. Majumder K, Chakrabarti S, Davidge ST, Wu J. Structure and activity study of egg protein ovotransferrin derived peptides (IRW and IQW) on endothelial inflammatory response and oxidative stress. J Agric Food Chem. 2013; 61(9): 2120-9.

37. Huang W, Chakrabarti S, Majumder K, Jiang Y, Davidge ST, Wu J. Egg-derived peptide IRW inhibits TNF-alpha-induced inflammatory response and oxidative stress in endothelial cells. J Agric Food Chem. 2010; 58(20): 10840-6. 